Acta vet. scand. 1974, 15, 264-273.

From the Research Station of the Veterinary Institute, Skara, Sweden.

\title{
LIVER ABSCESSES IN INTENSIVELY FED CATTLE*
}

\author{
SERIAL INVESTIGATIONS OF SERUM PROTEINS
}

By

Göran Jönsson and Per Liberg

JÖNSSON, GÖRAN and PER lIBERG: Liver abscesses in intensively fed cattle. Serial investigations of serum proteins. Acta vet. scand. 1974, 15, 264-273. - An attempt was made to détermine the time of onset of liver abscesses in intensively fed calves. Determinations of serum proteins (total protein, albumin, globulin, albumin/ globulin ratio, agarose-gel electrophoretic separation and formol-gel test) and, in a part of the material, of serum-GOT and -GPT were made in serial samples taken once a month from 125 calves. Liver abscesses were found in $48(38.4 \%)$ when slaughtered at $6-7$ months of age.

Total protein and globulin increased, the albumin-globulin ratio decreased with increasing age. Calves with liver abscesses had a significantly $(0.05>P>0.01)$ higher globulin concentration at the last sampling. At this sampling the material was of a limited size and the difference has to be interpreted with caution. No other significant differences were found. Nor were any rises observed in S-GOT and S-GPT referable to the formation of liver abscesses.

Bacteriological studies were not made but, in analogy with observations on a similar animal material in another part of Sweden, the infectious agent in the liver abscesses was assumed to be Sph. necrophorus. The explanation of the almost absent changes in the serum proteins in calves with liver abscesses may be the low antigenicity of this bacterium.

In conclusion it is stated that the present serial investigations of the serum protein pattern in young cattle provide no definite guidance for establishing the time of onset of liver abscesses.

liver abscesses; Spherophorus necrophorus; serum protein; serum-GOT; formol-gel reaction.

Liver abscesses have been found in different parts of the world to be considerably more common in intensively fed beef cattle, e.g. feedlot cattle in the USA and barley-beef in the UK, than in other cattle. The direct cause of liver abscesses is in most

* The investigations were carried out with financial support from the Swedish Council for Forestry and Agricultural Research. 
cases an infection with Spherophorus necrophorus (Simon \& Stovell 1971, Jensen \& Mackey 1971). In Swedish investigations of liver abscesses in mature cattle, especially dairy cows, Corynebact. pyogenes has been found in the majority of cases, while Sph. necrophorus was present in pure culture only in about $10 \%$ of cases (Rubarth 1960). More recent investigations of liver abscesses in intensively fed calves, however, have shown a marked predominance of the last-mentioned infectious agent (Månsson 1973).

The infectious agent enters the liver via $V$. portae, since abscesses do not occur primarily in other organs. The route of infection must thus be through the digestive tract. The most common notion is that the infection derives from pathological changes particularly in the wall of the rumen, rumenitis and ulcers (Smith 1944, Jensen et al. 1954 a). These are caused in turn by the special diet used in intensive feeding with restrictive roughage and with concentrate ad lib. (Jensen et al. $1954 \mathrm{~b}$, Ellis 1965, Mullen 1972, Rothenbacher et al. 1972, among others). Objections have, however, been raised against the view of an intimate relation between dietary lesions of the rumen wall and the occurrence of liver abscesses. Rowland (1966) compared the incidences of rumen-wall and liver lesions in intensively fed animals (barley-beef) with the incidences in traditionally fed animals and found them to be roughly equal. Robinson et al. (1951) observed no relation between the incidence of liver abscesses and either diet or fattening time. Animals taken direct from pasture to slaughter had as high an incidence of liver abscesses as feedlot animals.

The oommonest form of intensive feeding of calves in Sweden is in principle the same as for barley-beef, but the calves are slaughtered at about 6 months of age as the carcass weight may not exceed $125 \mathrm{~kg}$. The incidence of liver abscesses is often very high but varies greatly both between herds (from a couple up to about $35 \%)$ and between different batches within the herds. The feeding, especially within but also to a large extent between herds, is strictly standardized. The variation in incidence of liver abscesses would therefore be difficult to explain, if the feeding had a strongly decisive pathogenetic significance. Some observations in practice indicate that the incidence has been highest in herds or in batches where the calves have had severe episodes of diarrhoea. In this type of feeding viral infections, among which 
infection with bovine virus diarrhoea, are common (Jacobsson 1972). The latter infection causes such injuries in the digestive tract that they may very well serve as route of infection for Sph. necrophorus.

The time of onset of the liver abscesses is not known. A knowledge on this point might cast light on their pathogenesis. Abscesses in adult cattle, e.g. in connection with chronic traumatic peritonitis, cause manifest changes in the protein pattern of the blood serum (Björck \& Jacobsson 1964, Liberg 1973). Kimata et al. (1971) noted elevated total protein and globulin concentrations in conjunction with liver abscesses in 2-year-old cattle. The object of the present investigation was, through serial studies of, among other factors, changes in the protein pattern of blood serum from intensively fed calves, to attempt to establish the time of onsel of the liver abscesses.

\section{MATERIAL AND METHODS}

The material consisted of 125 calves from five herds, $90 \%$ of the calves being males. About $85 \%$ were Swedish red-andwhite, the remainder Swedish Holstein Friesian or a cross between the two breeds. The calves were purchased at about 2 weeks of age and were slaughtered on an average about 6 months later. Blood samples were taken within one week of purchase and thereafter at 1 -month intervals until slaughter.

Calves of these herds were subjected to specialized intensive feeding, with annual slaughter of an average of some 300 in each herd, and all herds had earlier had a high incidence of liver abscesses.

In conjunction with slaughter a thorough inspection was made of liver, rumen, lungs and heart. In the liver, records were made in particular of abscesses and scars. The rumen was examined macroscopically in respect of degree of pigmentation, presence and site of clumped villi ("rosebuds") and inflammatory reaction. These latter parameters were judged according to a $0-5$ scale, 0 being absence and 5 abundance of these reactions. In the lungs particular noie was made of acute and chronic pneumonias.

Slaughter weights were recorded for 67 calves, about $50 \%$ of the total.

Formol-gel reaction was tested ad modum Liberg (1973). 
Total protein was determined by the biuret method.

Albumin was determined ad modum Doumas et al. (1971).

Globulin concentration and $A / G$ ratio were calculated on the basis of the total protein and albumin values.

The serum proteins were separated by agarose-gel electrophoresis.

Serum-GOT and serum-GPT were determined by AB KABI's standard methods.

The material was divided on the basis of the necropsy findings into three groups: one with liver abscesses with or without simultaneous pneumonia (liver abscess group), one group with exclusively pneumonia (pneumonia group), and a third group in which neither liver abscesses, pneumonia nor othor manifest sign of disease was observed (normal group).

Liver abscesses with or without simultaneous pneumonia were observed in $48(38.4 \%)$ of the calves, pneumonia alone in $46(36.8 \%)$, while the remainder had no manif est morphological symptoms. Of the 48 animals in the liver abscess group, however, five had solely scars, which were presumed to be healed liver abscesses. The incidence of liver abscesses in the various herds varied between about 20 and $50 \%$.

Examinations of blood serum were made of all animals in the liver abscess and pneumonia groups, and of 10 in the normal group. Owing to the commencement of slaughter the number of animals at the seventh sampling had been reduced to 24,17 and 5 in the respective groups.

\section{RESLILTS}

Of the 64 animals for which the carcass weights were recorded 27 had liver abscesses. The average carcass weight of the latter was $122.5 \mathrm{~kg}$, that of the animals without liver abscesses $114.4 \mathrm{~kg}$. As regards the macroscopic ruminal changes, pigmentation and "rosebuds", the mean values according to the 5-degree scale were, respectively, 2.3 and 2.0 for animals with liver abscesses, 2.5 and 1.7 for animals without liver abscesses. None of the differences were statistically significant.

The protein determination showed an increase of total protein and globulin and a lowering of the $A / G$ ratio with rising age (Fig. 1). In a comparison within ages between the liver abscess, pneumonia and normal groups occasional mean values were 


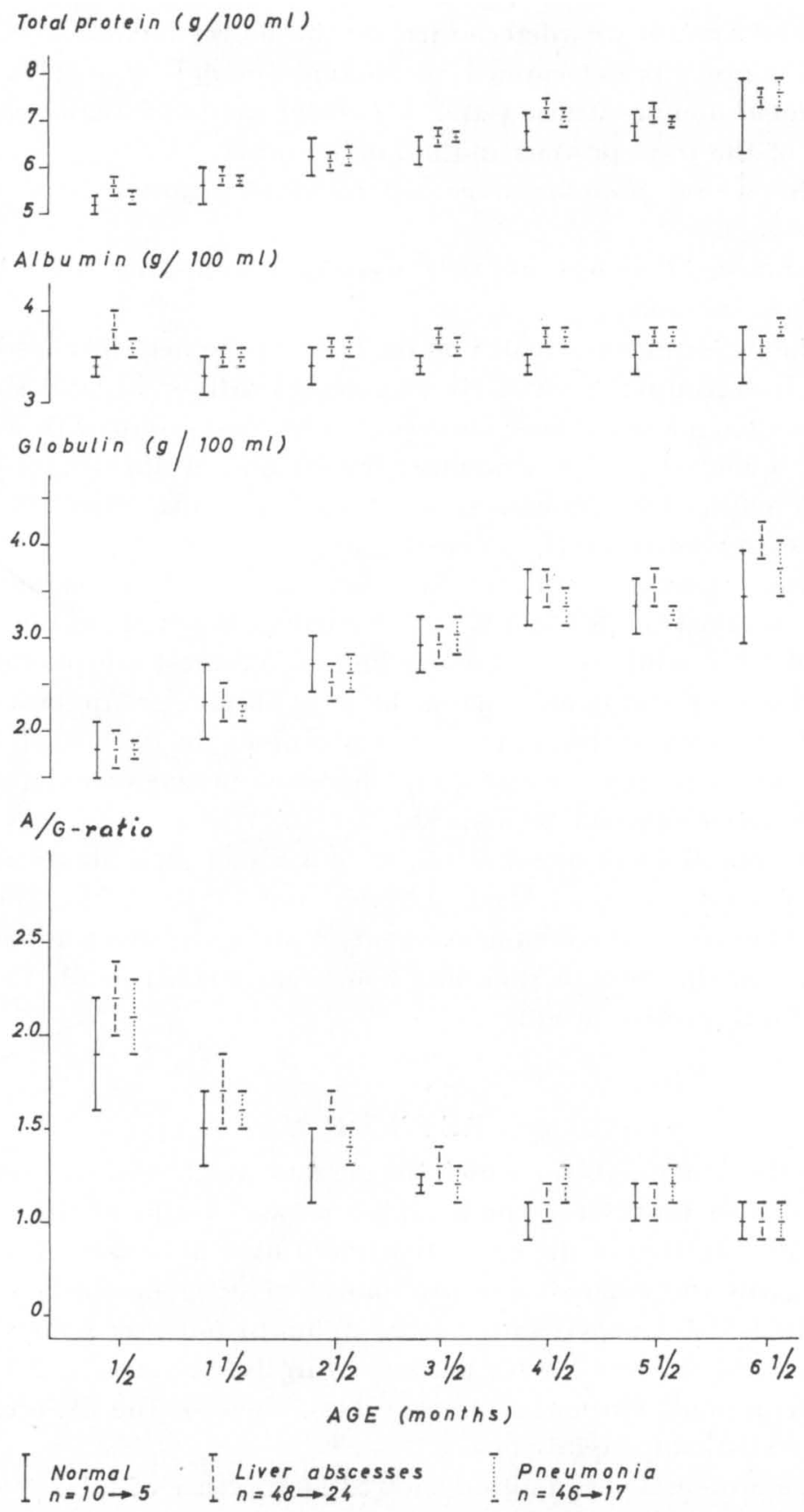

Figure 1. Total protein, albumin and globulin concentrations and the ratio albumin/globulin at rising ages in normal calves and in calves with liver abscesses and pneumonia respectively. ( $\bar{x} \pm 95 \%$ conf. int.). 
found which differed significantly from the remainder. For instance the globulin concentration in the liver abscess group was significantly $(0.05>\mathrm{P}>0.01)$ higher than in the normal group at the last sampling.

Agarose-gel electrophoretic serum protein separations with visual assessment showed no changes or variations in the protein pattern which might reflect the presence or development of liver abscesses.

Formol-gel tests were made on 663 serum samples, in which the globulin concentration was also determined. Fifty-three samples $(8 \%$ ) were FR-positive (globulin concentration $\overline{\mathrm{x}}=4.3 \mathrm{~g}$ / $100 \mathrm{ml}$ ). In 56 samples the globcilin concentration was $\geq 4.0 \mathrm{~g} /$ $100 \mathrm{ml}$, of which 37 samples were FR-positive (globulin concentration $4.5 \mathrm{~g} / 100 \mathrm{ml}$ ) and $19 \mathrm{FR}$-negative (globulin concentration $4.2 \mathrm{~g} / 100 \mathrm{ml})$.

All FR-positive samples derived from the liver abscess and pneumonia groups. From the finst four samplings there were only four FR-positive samples. Thereafter the incidence was higher and rose with rising age. The incidence of positive samples was numerically but not significantly higher in the liver abscess than in the pneumonia group at the sixth and seventh samplings.

Enzyme determinations were made for the normal and liver abscess groups (Table 1). In the liver abscess group 33 of altogether 306 GOT determinations exceeded 100 Karmen units. Of these 33 only 2 exceeded 200 Karmen units, with a maximal value of 668. Of the altogether 62 determinations for GOT activity

T a b l e 1. GOT-values (Karmen units) in serum of calves of different ages with and without liver abscesses.

\begin{tabular}{|c|c|c|c|c|c|c|c|c|c|}
\hline & & \multicolumn{8}{|c|}{ Age (months) } \\
\hline & & $1 / 2$ & $11 / 2$ & $21 / 2$ & $31 / 2$ & $41 / 2$ & $51 / 2$ & $61 / 2$ & $71 / 2$ \\
\hline $\begin{array}{l}\text { no liver- } \\
\text { abscesses }\end{array}$ & $\begin{array}{l}\quad \mathrm{n} \\
\overline{\mathrm{x}} \pm 95 \% \text { conf. } \\
\text { int. } \\
\text { highest value }\end{array}$ & $\begin{array}{c}10 \\
43 \pm 6 \\
62\end{array}$ & $\begin{array}{c}10 \\
67 \pm 17 \\
132\end{array}$ & $\begin{array}{c}9 \\
74 \pm 10 \\
94\end{array}$ & $\begin{array}{c}9 \\
81 \pm 21 \\
138\end{array}$ & $\begin{array}{c}10 \\
73 \pm 11 \\
94\end{array}$ & $\begin{array}{c}9 \\
82 \pm 12 \\
98\end{array}$ & $\begin{array}{c}5 \\
72 \pm 16 \\
94\end{array}$ & $\begin{array}{l}- \\
-\end{array}$ \\
\hline $\begin{array}{l}\text { liver- } \\
\text { abscesses }\end{array}$ & $\begin{array}{l}\quad \mathrm{n} \\
\overline{\mathrm{x}}+95 \% \text { conf. } \\
\text { int. } \\
\text { highest value }\end{array}$ & $\begin{array}{c}49 \pm 7 \\
144\end{array}$ & $\begin{array}{c}80 \pm 7 \\
154\end{array}$ & $\begin{array}{c}83 \pm 8 \\
218\end{array}$ & $\begin{array}{c}80 \pm 4 \\
116\end{array}$ & $\begin{array}{c}94 \pm 26 \\
668\end{array}$ & $\begin{array}{c}79 \pm 6 \\
144\end{array}$ & $\begin{array}{c}84 \pm 9 \\
154\end{array}$ & $\begin{array}{c}9 \\
87 \pm 17 \\
140\end{array}$ \\
\hline
\end{tabular}


in the control group only 2 exceeded 100 Karmen units, with a maximal value of 138 .

Parallel determination of GPT activity in the 20 samples with highest GOT activity showed close conformity between the activities of the two enzymes.

\section{DISCUSSION}

In conjunction with chronic inflammatory processes marked changes generally occur in the blood serum protein pattern, with increased globulin and lowered albumin concentration. In adult cattle this is particularly manifest in conjunction with suppurative processes (Björck \& Jacobsson 1964, Liberg 1973).

Kimata et al. (1971) showed in three 2-year-old cattle with liver abscesses that the total protein and globulin, especially $\gamma$-globulin, concentrations in serum were considerably higher than in animals of the same age without abscesses. The available literature contains no other investigations of the protein pattern in young cattle with liver abscesses. The present investigation revealed no assured changes of protein pattern in calves with liver abscesses. The higher globulin concentration at the seventh sampling (Fig. 1) must be interpreted with caution owing to the limited size of the material on that occasion. No bacteriological studies were made but it may be assumed that, in analogy with observations on similar animal material in another part of Sweden (Månsson 1973), the infectious agent in most of the cases was Sph. necrophorus. The explanation of the absence of change in the serum proteins may therefore be the low antigenicity of this bacterium. It produces agglutinating antibodies in the serum of several animal species, but in conjunction with liver abscesses in cattle the rise of antibodies has proved to be very slight (Feldman et al. 1936).

Since the presence of liver abscesses does not appear definitely to have affected the globulin concentration in blood serum, it is not to be expected either that the formol-gel reaction would be usable for the diagnosis of this complaint. It is probable that the use of FR for diagnosis of inflammatory processes in calves is also limited by the fact that they normally have low globulin concentrations and that the rise of globulin therefore must be greater in calves than in mature cattle before the limit is reached at which FR generally becomes positive (Liberg). 
Determinations of serum enzyme activities (S-GOT and S-OCT) on a single occasion are of no value for establishing the presence of liver abscesses (Holtenius d Jacobsson 1966). This would hardly be expected other than in an initial stage of the abscess formation associated with cellular disintegration. But nor have the present investigations of S-GOT activity in a series of samples shown any rise referable to liver abscesses. This confirms the results of previously reported investigations (El-Sabban et al. 1971).

In conclusion it may be stated that the present serial investigations of the serum protein pattern in young cattle with liver abscesses provide no definite guidance for establishing the time of onset of the abscesses.

\section{REFERENCES}

Björck, G. \& S.-O. Jacobsson: Elektrophoretische Untersuchung des Blutserums von Kühen mit chronischer traumatischer Peritonitis. (An electrophoretic investigation of blood serum in cows with chronic traumatic peritonitis). III Int. Meet. Diseases of Cattle, Copenhagen 1964, 382-388.

Doumas, B. T., W. A. Watson \& H. G. Biggs: Albumin standards and the measurement of serum albumin with bromcresol green. Clin. chim. Acta 1971, 31, 87-96.

Ellis Jr., G. F.: All-concentrate feeding research. Feedstuffs 1965, 37, $50,54-55$.

El-Sabban, F. F., H. Rothenbacher, T. A. Long \& B. R. Baumgardt: Certain blood constituents and serum transaminases in Hereford steers fed high-energy rations. Amer. J. vet. Res. 1971, 32, 1027-1032.

Feldman, W. H., H. R. Hester \& F.P. Wherry: The occurrence of Bacillus necrophorus agglutinins in different species of animals. J. infect. Dis. $1936,59,159-170$.

Holtenius, P. \& S.-O. Jacobsson: Ornithine-carbamyl transferase (OCT) activity in ruminants. Cornell Vet. 1966, 56, 187-195.

Jacobsson, S.-O.: Aktuella akuta infektionssjukdomar hos nöt. (Current acute infectious diseases in cattle). Proc. Allmänt veterinärmöte, Stockholm 1972, II, 23-32.

Jensen, R. \& D. R. Mackey: Diseases of feedlot cattle. 2nd Ed. Lea \& Febiger, Philadelphia 1971.

Jensen, R., H. M. Deane, L. J. Cooper, V. A. Miller \& W. R. Graham: The rumenitis-liver abscess complex in beef cattle. Amer. J. vet. Res. 1954 a, 15, 202-216.

Jensen, R., W. E. Connell \& A. W. Deem: Rumenitis and its relation to rate of change of ration and the proportion of concentrate in the ration of cattle. Amer. J. vet. Res. 1954 b, 15, 425-428. 
Kimata, H., T. Tsunekana, Y. Sugaura, T. Watanabe \& Y. Kurabayashi: Studies on the diagnostic method in fattening calves with hepatic abscesses. Bull. College Agric. vet. Med., Nihon University $1971,28,42-54$.

Liberg, P.: The formol-gel reaction in cattle. Acta vet. scand. 1973, 14, $712-722$.

Mullen, P. A.: Intensive beef production -- barley beef. Vet. Bull. (Weybridge) 1972, 42, 119-124.

Månsson, I.: 1973. Personal communication.

Robinson, T. J., D. E. Jasper \& H. R. Guilbert: The isolation of Spherophorus necrophorus from the rumen together with some feed lot data on abscess and telangiectasis. J. Animal Sci. 1951, 10, $733-741$.

Rothenbacher, H., F. F. El-Sabban, T. A. Long \& B. R. Baumgardt: Prevention of stomach and liver pathology in feeder steers by sawdust roughage replacer. Vet. Med./Small Animal Clin. 1972, $67,1127-1133$.

Rowland, A. C.: Some aspects of the rumenitis/liver abscess complex in traditional and in intensively managed beef cattle. Vet. Rec. 1966, 78, 713-716.

Rubarth, S.: Hepatic and subphrenic abscesses in cattle with rupture into Vena cava caudalis. Acta vet. scand. $1960,1,363-382$.

Simon, P. C. \& P. L. Stovell: Isolation of Sphaerophorus necrophorus from bovine hepatic abscesses in British Columbia. Canad. J. comp. Med. 1971, 35, 103-106.

Smith, $H$. A.: Ulcerative lesions of the bovine rumen and their possible relation to hepatic abscesses. Amer. J. vet. Res. 1944, 5, 234242.

\section{SAMMANFATTNING \\ Leverabscesser hos intensivt uppfödda kalvar. Serieundersökningar av serumproteiner.}

För att försöka bestämma tidpunkten för uppkomsten av leverabscesser hos intensivt uppfödda kalvar gjordes bestämningar av serumproteiner (totalprotein, albumin, globulin, AG-kvot, agarosgelelektroforetisk separation samt formol-geltest) och på en del av materialet av serumaktiviteten av GOT och GPT i serieprover, tagna en gång per månad på 125 kalvar. Leverabscesser konstaterades hos 48 st $(38.4 \%)$ då de slaktades vid 6-7 månaders âlder.

Totalprotein och globulin ökade medan AG-kvoten minskade med stigande ålder. Kalvar med leverabscesser hade signifikant $(0.05>P$ $>0.01$ ) högre globulinkoncentration vid sista provtagningen. Materialets begränsade storlek vid detta tillfälle gör att skillnaden måste tolkas med försiktighet. Inga andra signifikanta skillnader konstaterades. Någon ökning av serum GOT och GPT som kunde hänföras till leverabscessernas uppkomst, observerades inte.

Bakteriologiska undersökningar utfördes inte men det antas att - i analogi med observationer på liknande djurmaterial i en annan 
del av Sverige - infektionsämnet i leverabscesserna var Sph. necrophorus. Förklaringen till de uteblivna förändringarna i serumproteiner hos kalvar med leverabscesser skulle kunna vara denna bakteries låga antigenicitet.

Som slutsats framhălles att de utförda serieundersökningarna över serumproteinmönstret hos unga nötkreatur inte ger någon ledning för att bestämma tidpunkten för leverabscessernas uppkomst.

(Received December 17, 1973).

Reprints may be requested from: the Research Station of the Veterinary Institute, S-532 00 Skara, Sweden. 